\section{European geophysics} \section{Traverse planned}

Plans to involve geoscientists from all over Western Europe in a joint study of Europe's continental crust moved a step forward this month when a working group of the European Science Research Council all but finalized a proposal for the European Geotraverse project. The cost will exceed FF 22 million ( $f 1.8$ million).

The proposal will be considered by the European Science Foundation at its annual assembly in November. If it is approved, the 5-7 year project will be a test of whether the European science community can make such large-scale cooperation work.

The geotraverse will survey a swathe of continental crust extending $4,000 \mathrm{~km}$ from the northern tip of Scandinavia southwards to North Africa and will cover crustal ages ranging from the oldest, in the Precambrian areas of Scandinavia, decreasing southwards to the tectonically still-active Mediterranean region.

The traverse breaks down into three regions. The northern segment consists of the Baltic "Shield" and the regions just south of it, extending from the North Cape to north Germany. The Precambrian shield is between 600 and 3,600 million years old, while the neighbouring Caledonides in Scandinavia and north Germany are between 600 and 400 million years old. The Precambrian crust has remained essentially unaltered since the close of the Precambrian 600 million years ago and should contain evidence of palaeotectonic processes that may have taken place during the earliest stages of crustal development. For example, geochemical and morphological studies may yield evidence of early subduction processes beneath the surface, while palaeomagnetic measurements should reveal what, if any, plate motions occurred during this era.

South of the Baltic Shield lies a region of Precambrian basement overlain by a younger formation, several kilometres in thickness. It is hoped that deep seismic observations will show how the Baltic Shield extends into the basement and meets the younger Caledonide basement of north Germany.

The middle section of the traverse, from 400 to 230 million years old, coincides with the mountainous "Hercynian" area of Central Europe. Seismic mapping has revealed the complex structure of the upper mantle in this region, while several models exist for the tectonic processes leading to the mountain development. Deep seismological studies should demonstrate which models are correct, and petrological studies of young volcanic rocks should yield evidence on the composition of the deep crust. The substructure has been investigated by gravity measurements and the project may explain some of the anomalies discovered.

The southern section of the traverse includes the Alps, the Po basin, the western Mediterranean and the north continental margin of Africa. This region has been dominated by Alpine mountain-building and, further south, by the relative movement of African and European plates. The combination of geophysical and geochemical techniques will, it is hoped, answer such fundamental questions as how the height of the Alps varied with time and what processes produced the western Mediterranean basins.

The geotraverse project will be coordinated by the European Science Foundation, but the expenditure on science will be provided by the respective funding bodies of the participating countries. Moreover, as well as the largescale coordinated interdisciplinary experiments along the traverse, the project requires smaller-scale regional programmes to provide supplementary information. Thus, although the European Science Foundation may approve the project in November, it will be up to the individual countries to make the enterprise work. At present the signs are very favourable.

Philip Campbell

\section{Appealing primates}

The smallest monkeys in the world are alive and thriving in the Charles Clore Pavilion for Small Mammals at London Zoo. The new exhibition, "The World's Smallest Monkeys", which runs until the end of October (free entry for visitors to the zoo), is part of a campaign to attract visitors and to focus attention on small and distant primates, the marmoset and tamarin monkeys.

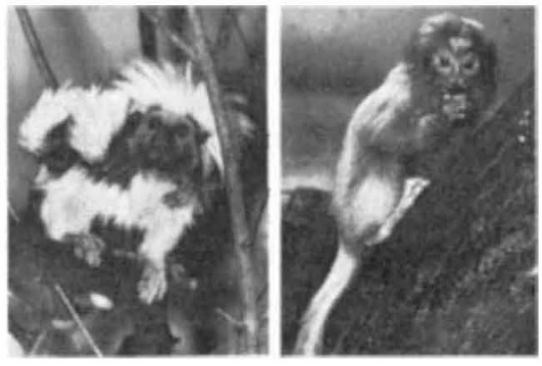

A cotton-headed tamarin with twins (left) and a golden lion tamarin, all to be seen at London Zoo

Their natural habitat, the tropical forests of South America, is rapidly being destroyed and 12 of the 15 different species are now seriously at risk. The zoo hopes the public will be made aware of these species of monkeys - the pygmy marmoset weighs only about 100 grammes and is difficult enough to spot in its zoo habitat - and also wishes to highlight its conservation work. The golden lion tamarin and cotton-headed tamarin are both virtually extinct in the wild but have bred successfully at the zoo. Both are potentially important laboratory primates. Their small size has both a practical advantage and, it is hoped, large public appeal.

\section{Romanian agriculture Meat over bread}

The Romanian leadership has this month published a grand design to reform the nation's eating habits and to eliminate nutritional diseases. But can Romanian agriculture meet the challenge?

The programme is nutritionally conventional. The targets for 1985 include a drop in calorie intake from the present average daily intake of 3,300 calories per head of population to $2,800-3,000$, an emphasis on lean meat and dairy products and a reduction of the proportion of cereals in the diet from the present 45 per cent to about 38 per cent. Fat and sugar consumption is to go down, and the balance is to be provided by vegetables and fruit. By 1985, the plan is that the average Romanian will consume $80 \mathrm{~kg}$ of meat and fish and 230 litres of milk a year.

The programme gives no hint, however, of where the new diet is to come from. Food queues and shortages are endemic in Romania and agriculture is in disarry. Last year, President Nicolae Ceausescu castigated agricultural students who do not intend to work on farms but who simply see their diplomas as entrance tickets to the civil service. During the past three months, high-level reorganization of the agricultural ministries has been accompanied by veiled allusions to slacking and corruption.

The new programme reiterates the need for local self-sufficiency. Fortunately Romania's only major conurbation Bucharest, with a population of 1.8 million - is prudently coupled for administrative purposes with the Ilfov farming district. In the event, food rationing was introduced last autumn, concurrently with selfsufficiency. The present rations $(1 \mathrm{~kg}$ per person per month of meat, flour and sugar, and 1.5 litres of cooking oil) compare oddly with the high-protein diet prescribed for 1985.

If the nutrition targets are to be met, some means must be found to reverse the falling trends of meat production. A scheme worked out by the Academy of Agricultural and Forestry Sciences may help. It advocates a complex system of research and planning in which multidisciplinary teams would work towards an integrated zootechnology to raise the quality and quantity of meat production.

The immediate bottleneck in Romanian food production, however, is in fodder and cereal production. In this respect, the reduction of human cereal consumption now proposed makes sense. Cereal production is not intensive - the target yield of 24 million tonnes for 1982 works out at less than 4 tonnes per hectare. A drop in bread consumption would leave more cereals available for animal feed. But the immediate outlook is one of tightened belts and severe rationing. 